\title{
ACHIEVEMENTS OF THE SADF 1961 - 1982
}

Lt D Conradie*

The founding of the Republic of South Africa in May 1961 had, according to International Law, no significant implications for existing international military agreements such as the Simonstown Agreement. However, with South Africa no longer a member of the Commonwealth, certain aspects did change, eg. the erection of radar stations by the RSA in High Commission Territories had to be abandoned.

\section{The Arms Embargo - Spur for Self-sufficiency in Armament}

Just prior to South Africa becoming a republic, many African States insisted that the United Nations, and the Western countries should impose an arms embargo on the Republic. Such an appeal was made by the United Nations in August 1963, and in June 1964 an Arms Embargo was instituted against the RSA. In November 1964 the British Labour Government formally bound itself to uphold the arms boycott.

Although the arms embargo impeded South Africa's armaments purchase programme, the SADF still succeeded in acquiring helicopters, piston-engined aircraft, transport aircraft and high-performance jet aircraft like the Mirage and the Buccaneer. Modernization of the Air Force radar network commenced in 1966, and was completed in 1971. To facilitate all-weather flying operations, airfields were equipped with modern air traffic control and radio/radar approach aids. In 1971 a network of Decca Navigational Aids became operational.

\section{Establishment of the Armaments Board}

The changed attitude of the world towards the Republic of South Africa, and the United Nations Arms Embargo emphasized the need for armament self-sufficiency. Until that stage the armaments procurement organisation, the Munitions Production Office was a minor link in the RSA's defence. It was quite clear that this organisation would be inadequate for meeting the new challenge. This situation led to the establishment of the Armaments Board in terms of the Armaments Act, 1964. The Armaments Board was instituted in December 1964.

The main function of the Armaments Board was the provision of armaments for the SADF. Procurement was made either through foreign purchases or local manufacture after obtaining the licenses and know-how from overseas. The production of the Eland armoured car in 1963 is an example of this.

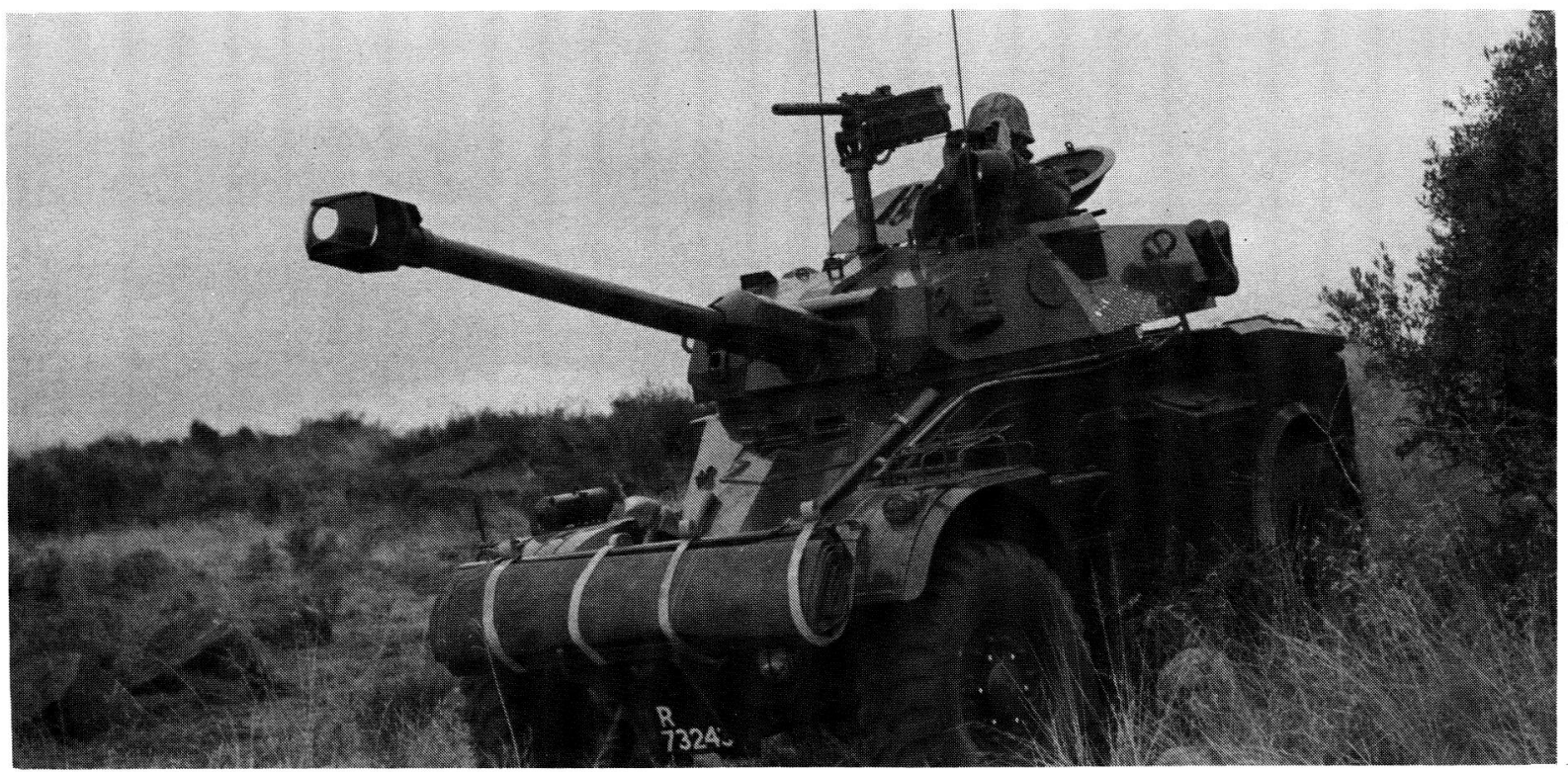

The Eland Armoured Car 


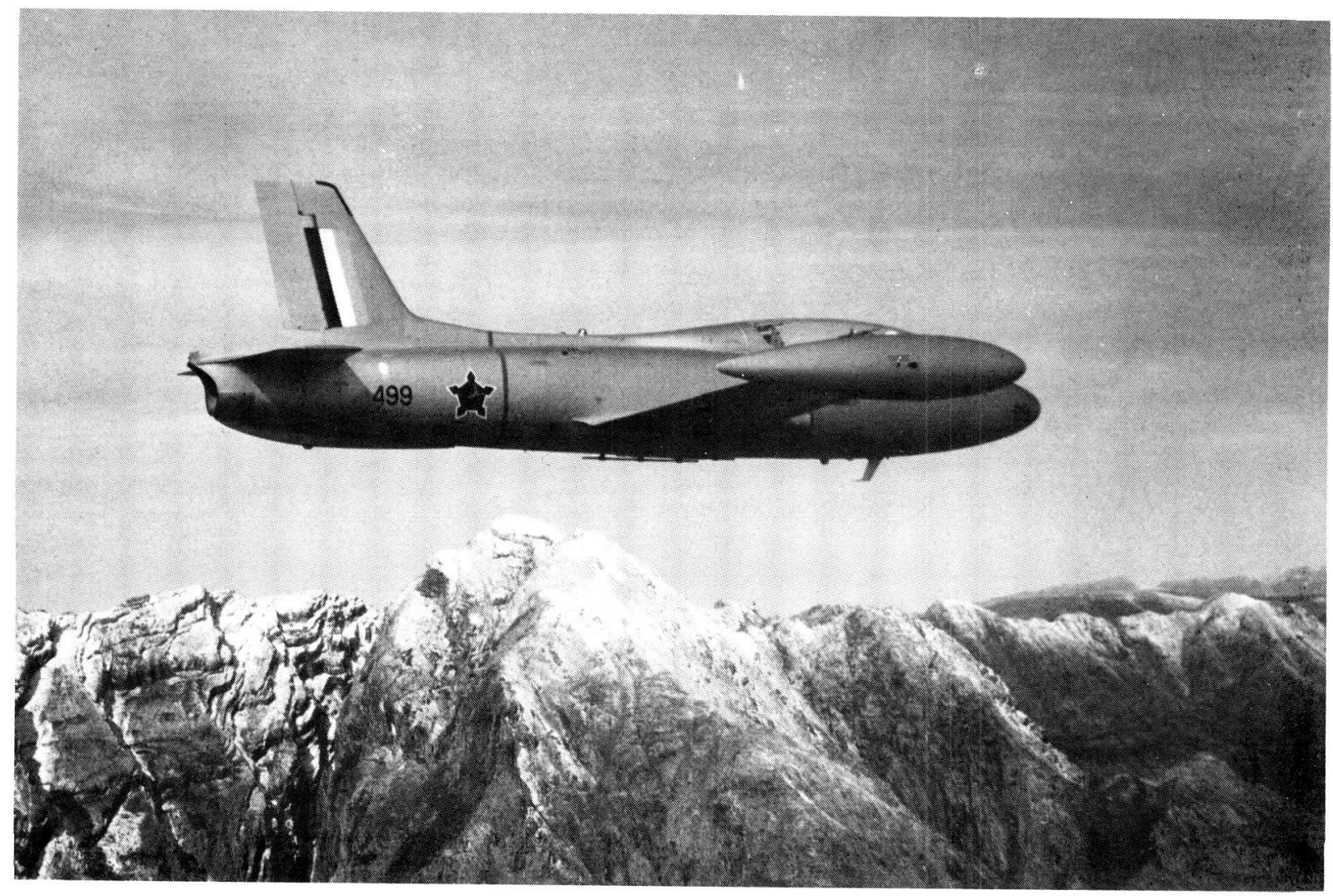

The Impala

Local manufacture was undertaken in all cases where this proved practical; practical meaning technically practicable, economically acceptable and strategically essential. In general it was experienced that in cases where the quantities to be manufactured were comparable with overseas quantities, local prices were competitive and sometimes even lower.

The aircraft industry was established in South Africa in 1967, with the founding of the Atlas Corporation which undertook production of the Impala Mk I jet trainer.

\section{Establishment of an Armaments Development and Production Corporation (ARMSCOR)}

With the aim of accelerating the armaments programme in mind, the functions of the Armaments Board were expanded by means of the Armaments Amendment Act of 1968. This expansion included control over research, and the procurement of defence stores. As a result of the broader scope of the Board's activities, and to enable the Board to concentrate more on the procurement of Defence requirements, the Armaments Development and Manufacturing Cor- poration (Armscor) was established to relieve the Board of the manufacturing functions.

\section{Introduction of National Service}

In 1960 a ballot system existed, through which a certain number of men were annually balloted to undergo military training. This training period extended over three months per year only, but this was increased to nine months in 1962.

However, it became apparent that the system would have to be overhauled due to changing circumstances. Act 85 of 1967, amending the Defence Act, 1957, effected far-reaching changes in the National Service system. In terms of this Act continuous training was extended to a maximum of 12 months. The ballot system fell away, and was superseded by annual selection lists in respect of all National Servicemen for the subsequent year. All National Servicemen were compelled to render service either in the Citizen Force or in the Commandos.

\section{Introduction of the Ten Year Plan}

The arrival of the 1970's left no one in the Republic in doubt as to the difficult times ahead. The 


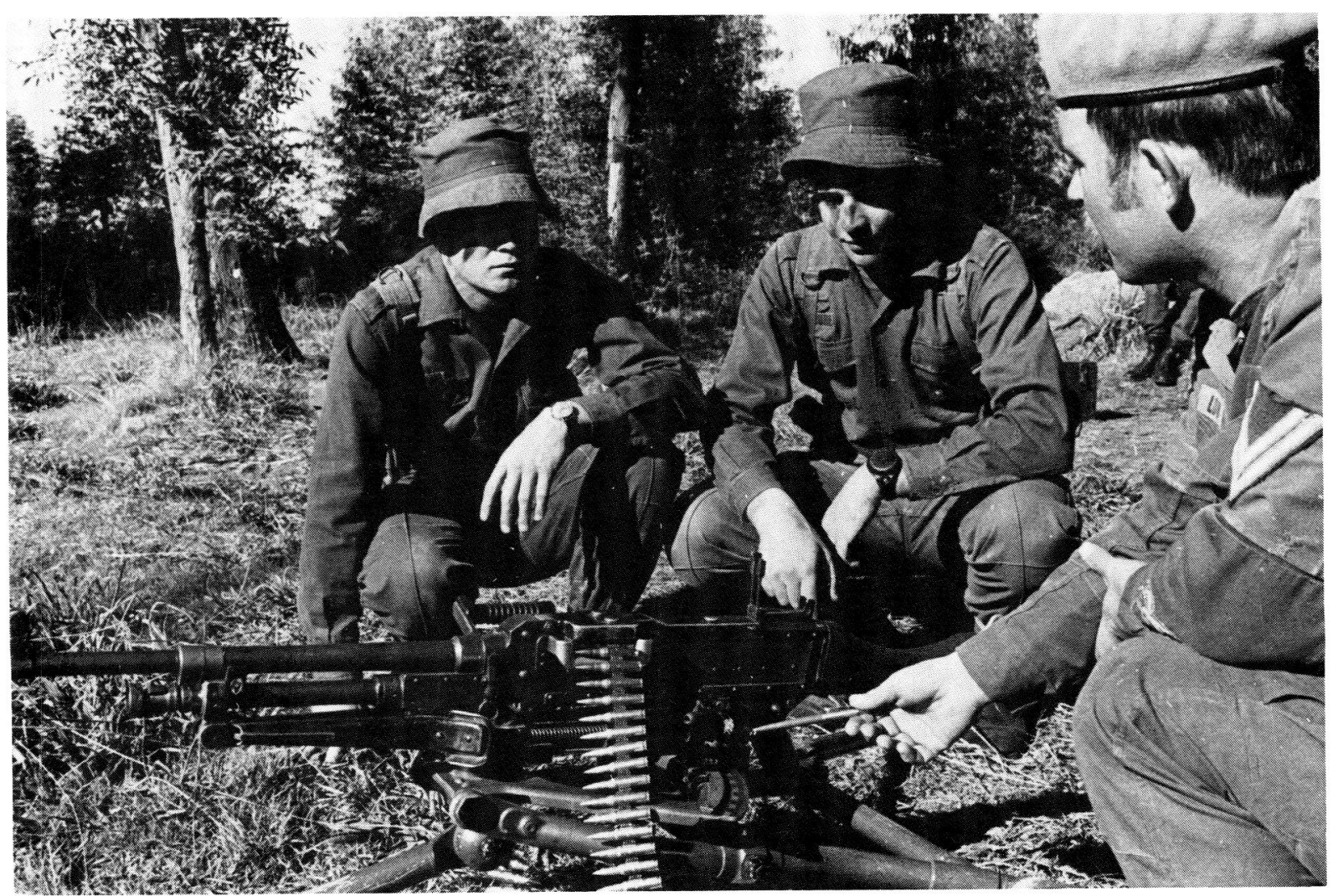

National Servicemen receive instruction in the use of the Machine Gun

changed crrcumstances in world politics necessitated a far-reaching review of the overall planning programme of the South African Defence Force. Not only did world opinion turn against South Africa, but the threat of war, unconventional as well as conventional, also increased.

In 1970 a ten year programme was submitted to the Government by the Chiefs of the Defence Force, according to which the Defence Force would develop to meet the threats against the RSA.

\section{Changes in Command and Control}

In 1972 a Defence Staff Council came into being. Its main concern was the management of the Defence Force. A council for advice on defence matters was also instituted. This was followed by the establishment of a Defence Command Council (DCO), and a Defence Planning Committee (DPC).

The structure of the SA Army was modified to facilitate the control of counter-insurgency operations. To co-ordinate and integrate all actions by the SADF in the northern areas of SWA, the headquarters of 101 Task Force was instituted.
On the national level the State Security Council was instituted, to assist the Cabinet in matters concerning the national security of the RSA.

In July 1979 the fourth service arm of the Defence Force, the South African Medical Service, was established; the other three arms consisting of the SA Air Force, SA Army and SA Navy.

\section{Solving the manpower problem}

Manpower problems are a source of concern which is not alien to the SADF. Various measures have been taken to combat this.

In 1972 the first women were given the opportunity to join the SADF for a period of one year. By the end of 1972, 265 women completed their training at the SA Army Women's College at George.

It was also decided to employ other population groups in the SADF. In January 1973 training for Coloureds commenced at Eerste Rivier with the Cape Corps Service Battalion. 400 completed their training. In 1974 the first Black battalion, 21 Battalion, was established, and in January 1975 the first Indians were trained at Salisbury Island, Durban. It was also the year in which the first Coloured Officers were appointed. 
Another source of manpower is tapped through the system of National Service, which, since 1972 has been updated to meet the requirements of the SADF in combatting the growing threat. A new system will come into operation in 1983, and will entail an initial service period of 2 years continuously, followed by 12 years of training camps. To meet the terrorist threat, the Commando-system is also updated.

\section{War in Angola}

1974 saw the collapse of the Portuguese colonial regime in Angola and Mocambique. This constituted an immediate danger to South African interests in South West Africa, as Cuban forces became involved in the ensuing civil war in Angola. In an effort to protect South African interests at Ruacana and Calueque, the SADF moved into Southern Angola. In the event South African forces clashed with Cuban forces. The South Africans acquitted themselves well; illustrating that they had lost none of the fighting spirit of their forefathers. In the end international pressure forced the withdrawal of the SADF from Angola.

\section{Operations against SWAPO}

The fall of Angola to the communists provided SWAPO with a "safe" haven to operate from. However, the safety of this haven was disproved in May 1978, when South African Forces struck at two of SWAPO's main bases, and destroyed them totally. Once again the fighting spirit of the South African soldier was illustrated. Confronted with unexpectedly fierce resistance, the South African soldiers rallied to the challenge, and emerged victorious.

Since that first raid, codenamed Reindeer, the SADF has launched several other operations of a similar nature; Sceptic, Protea, Daisy and Super being the foremost.

Operation Protea, one of the largest operations launched by the South African Defence Force since World War II, produced pitched battles between the SADF and forces consisting of elements from SWAPO and the Angolan Armed Forces (FAPLA). These battles included the use of tanks and artillery by the communist forces. However, through superior training and a determination to prevail, the South Africans once again tasted the fruits of victory. It was during this operation that the presence of Soviet military personnel in FAPLA were proven with the capture of a Russian soldier.

\section{Armaments Production Increases}

The policy of armament development, armament research and the development of an own armament industry has been met with success. These successes include the development and production of the Ratel Infantry Fighting Vehicle (1977); the R4-Assault Rifle, as well as a rocket artillery system. The development and production of the Olifant tank and the G5-155mm artillery piece provided further proof of South Africa's capability. The unveiling of the G6-High Mobility Self Propelled Gun in 1982 came as a vivid illustraton of how South Africa's capability to produce sophisticated weapon systems has developed.

Other successes include the production of missiles, ammunition, as well as the production of light military aircraft, Impala Mkll jet aircraft as well as a Mirage-programme carried out by Atlas.

One of the highlights of 1982 was the opportunity to participate in the armaments display in Greece. It provided Armscor with the opportunity to enter the highly competitive international arms trade.

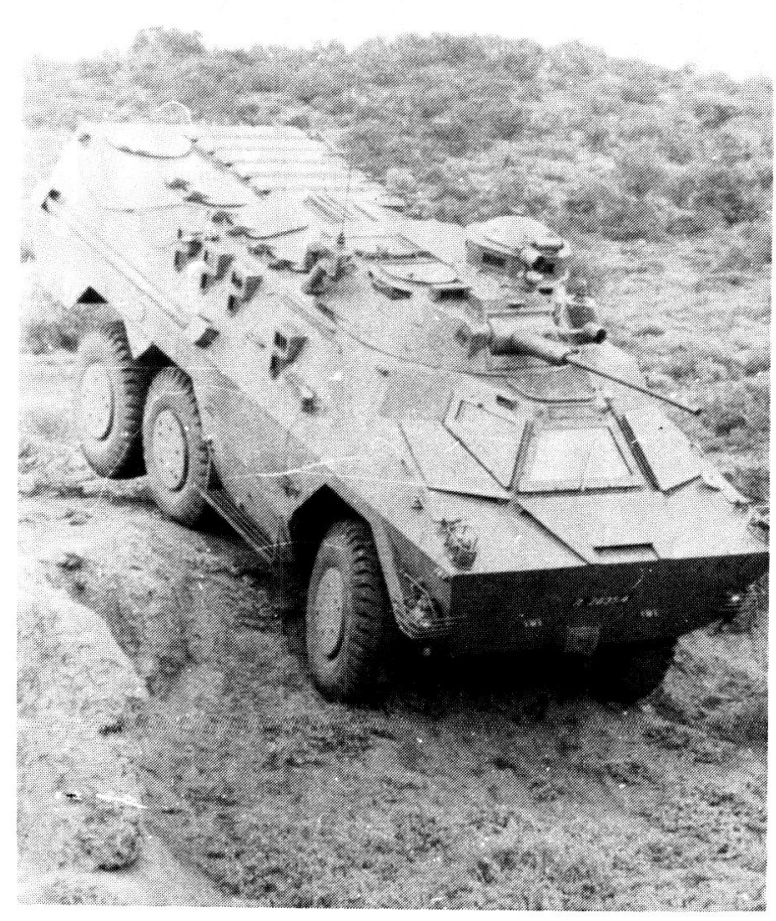

The Ratel Infantry Fighting Vehicle 


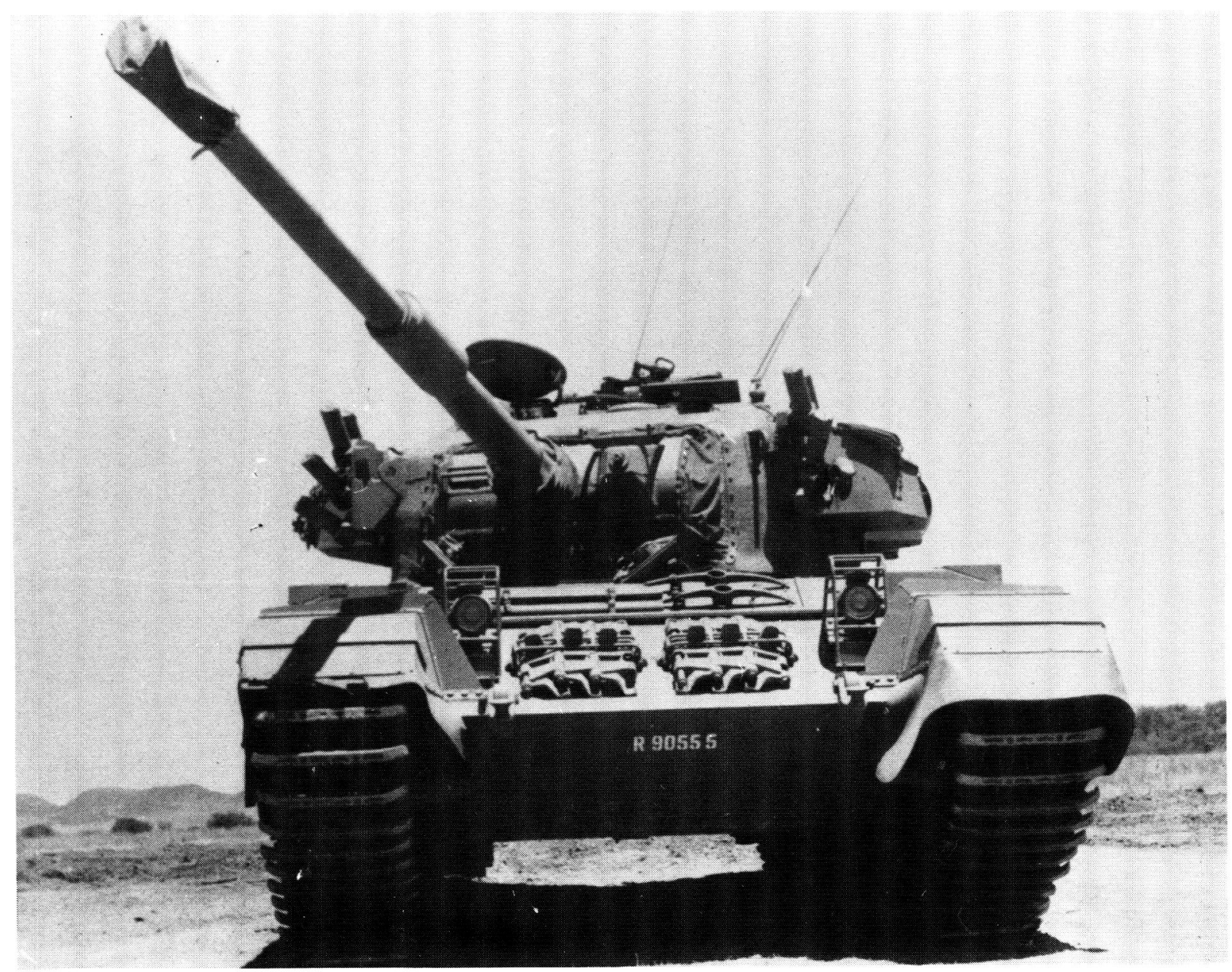

The Olifant Tank

\section{Developments in the Fighting Services}

\section{SA Army}

In the early seventies the Army took the first step in training horses and dogs for use in counterinsurgency operations. In 1973 the SA Army took over the defence of the northern borders of the Republic. In October 19737 and 8 Infantry Battalions were established. This enhanced the capability of the SA Army to prepare troops for battle.

\section{SA Air Force}

In 1972 the existing air defence system was modernized to meet future threats. The intercept capability of the SAAF was enhanced with the introduction of a computer-controlled radar sys- tem. Modern interceptor aircraft like the Mirage F-1, armed with missiles were introduced. 1973 saw the withdrawal of the Vampire from service, and the introduction of the South African manufactured Impala Mk2. The Kudu, a light support aircraft, also locally produced, became operational in 1977.

\section{SA Navy}

The decade of the seventies saw the completion of the Daphne Submarine Project which commenced in 1967. The Silvermine Maritime Operational Center was opened in 1973. This facility provided the SA Navy with a modern operational command and control system. The acquisition of the fast missile-armed strike craft provided the Navy with a sting and introduced the SA Navy to the missile era. 


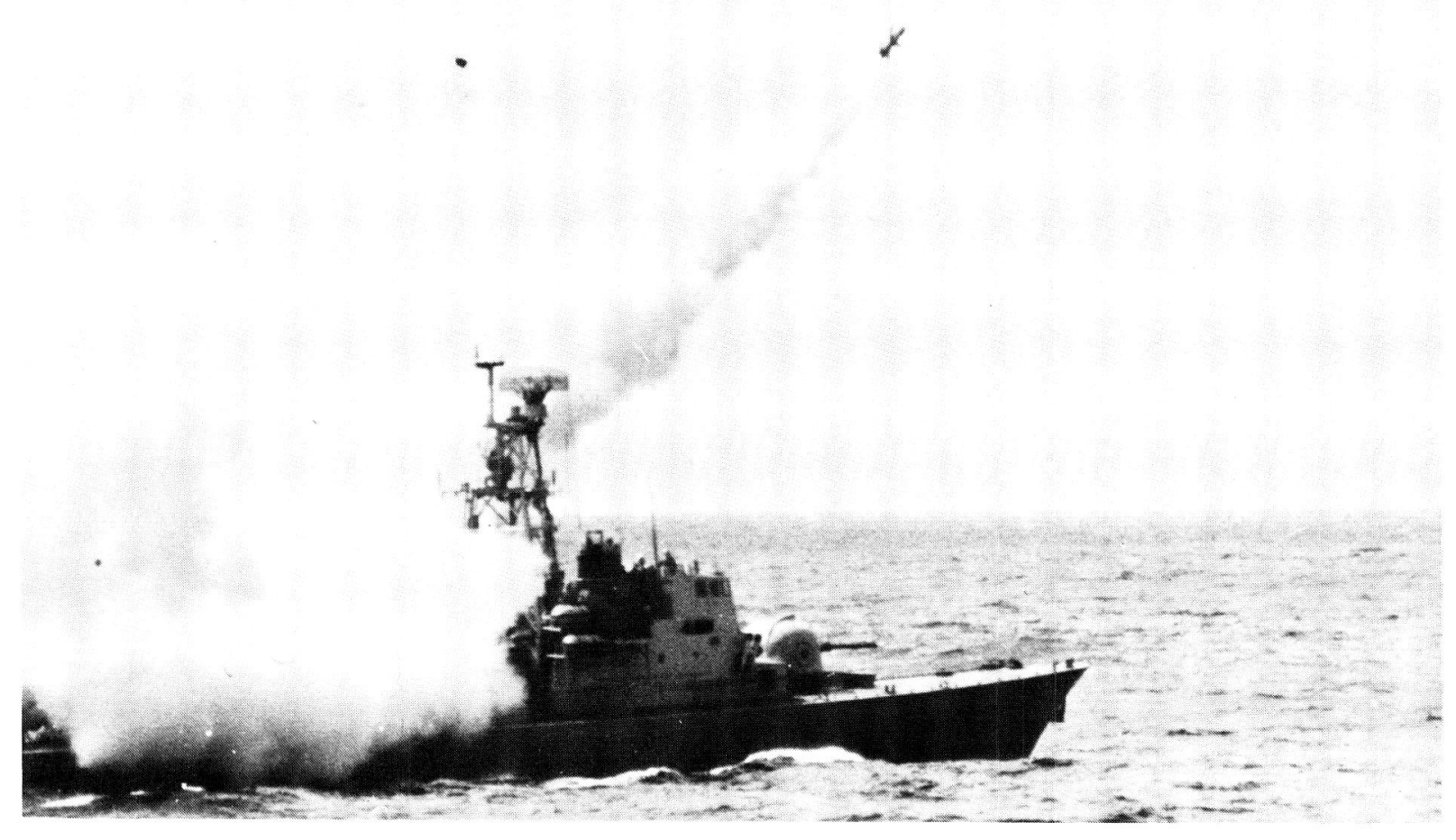

Testing the Skerpioen Missile

A quick scan through these developments can leave no one in doubt that during the past two decades the SADF has grown into one of the most effective, battle-ready armed forces in Africa. The lessons of the past have not gone unheeded. Judging from the present, the future bodes well for the South African Defence Force.
*Lt D. Conradie, BA, is attached to the Military Information Bureau of the SADF

\section{Bibliography}

1. Development of the South African Defence Force as an organisation from $1960-1980$

2. Review of Defence and Armaments Production: Period 1960 to 1970

3. White Papers on Defence and Armament Production; 1973 - 1979 editions. 